\title{
Abnormal Vasomotor System Function in Idiopathic Generalized Epileptic Patients
}

\author{
İdiopatik Jeneralize Epileptik Hastalarda Anormal Vazomotor Sistem Fonksiyonu
}

\author{
Mehdi Maghbooli1, Mehran Khesali Langroudi ${ }^{1}$, Abdoreza Ghoreishi1 ${ }^{1}$ Zari Shajari² \\ 1Zanjan University of Medical Sciences, Department of Neurology, Zanjan, Iran \\ 2Zanjan University of Medical Sciences, Metabolic Disease Research Center, Zanjan, Iran
}

\section{Summary}

Objective: Autonomic dysfunction is widely recognized in both partial and generalized epilepsies. The aim of this study was to evaluate the vasomotor response in patients with generalized idiopathic epilepsy using clinical autonomic function tests.

Materials and Methods: Hundred and twenty-four consecutive subjects including 62 idiopathic generalized epileptic patients diagnosed for more than 3 months receiving monotherapy and 62 matched for sex and age healthy controls were assessed in this case-control study. The evaluation of the vasomotor system was made using a questionnaire and autonomic function tests including cold pressor, Valsalva maneuver, mental arithmetic and hand-grip tests.

Results: Abnormal score of the Cold pressor test was seen in 59.7\%, Valsalva maneuver in $64.5 \%$ and $33.9 \%$ in mental arithmetic test of epileptic patients. These results were different significantly in comparison to control group. If abnormal hand grip test was defined as an increase less than $11 \mathrm{mmHg}$ in diastolic pressure, there was found no significant difference between two groups of case and control, also a few people in control group was reported normal. When abnormality was defined as an increase in only one or none of the parameters of systolic blood pressure, diastolic blood pressure or heart rate, $43.5 \%$ in patient group versus $14.5 \%$ in controls had abnormal results with statistically significant difference.

Conclusion: Vasomotor dysfunction assessed with cardiovascular tests was present in patients with generalized epilepsy. Further research on central and peripheral limbs in association with the breakdown of the system is required. (Turkish Journal of Neurology 2014; 20:126-131)

Key Words: Idiopathic epilepsy, vasomotor system, hand-grip, cold pressor, mental arithmetic, Valsalva maneuver

Conflict of interest: The authors reported no conflict of interest related to this article.

\section{Özet}

Amaç: Autonomic dysfunction is widely recognized in both partial and generalized epilepsies. The aim of this study was to evaluate the vasomotor response in patients with generalized idiopathic epilepsy using clinical autonomic function tests.

Gereç ve Yöntem: Üç aydan uzun süre önce teşhis konmuş 62 idiopatik jeneralize epileptik ve cinsiyet ile yaş olarak eşleştirilmiş 62 kontrol çalışmaya dahil edilmiştir. Vazomotor sistem değerlendirilmesi, bir anket ve soğuk presör, Valsalva manevrası, mental aritmetik ve el sıkma testi gibi otonomik fonksiyon testleriyle yapıld1.

Bulgular: Soğuk presör testinde anormal sonuçlar epileptik hastaların \%59,7'sinde, Valsalva manevrasında hastaların \%64,5'inde ve mental aritmetikte hastaların \%33,9'unda görülmüştür. Bu sonuçlar kontrol grubundan istatistiksel olarak anlamlı derecede farklıdır. El sıkma testi 11 mmHg'den daha küçük bir diastolik basınç artışı olarak tanımlandığında iki grup arasında fark yoktu ve hasta grubundan birkaçı tamamen normaldi. Anormallik, sistolik kan basıncı, diastolik kan basıncı veya nabız parametrelerinden sadece biri veya hiçbiri olarak kabul edildiğinde hasta grubunun \%43,5'ine karşın kontrol grubunun \%14,5'i anormallik gösteriyordu ve bu fark anlamlıyd.

Sonuç: Kardiyovasküler testler kullanılarak ölçülen vazomotor disfonksiyon jeneralize epilepsi hastalarında sıklıkla görülmüştür. (Türk Nöroloji Dergisi 2014; 20:126-131)

Anahtar Kelimeler: İdiopatik epilepsi, vazomotor sistem, el sıkma testi, soğuk presör, zihinsel aritmetik, Valsalva manevrası

Çıkar çatışması: Yazarlar bu makale ile ilgili olarak herhangi bir çıkar çatışması bildirmemişlerdir. 


\section{Introduction}

Partial and generalized epilepsies affect all aspects of autonomic function including the parasympathetic, sympathetic and adrenal medullary systems (1).

The pathophysiology of cardiovascular autonomic disruption during seizure can be explained as a generalized burst which may affect the brain as a whole, including central autonomic network. Seizures typically activate sympathetic nervous system, increasing the heart rate and blood pressure, although parasympathetic activation or sympathetic inhibition may predominate during partial seizures (2-4). Palpitations can occur without heartrate changes. Sinus tachycardia can occur in more than $85 \%$ of complex partial and tonic-clonic seizures $(5,6)$ and changes in blood pressure and cardiac rhythm frequently accompany epileptic seizures (7). Also, changes in blood pressure and cardiac rhythm and rate frequently are associated with epileptic seizures, and cardiovascular autonomic disturbance possibly is underlying pathogenesis of sudden, unexpected death in people with epilepsy (8-11).

Antiepileptic drugs (AEDs) can alter autonomic function. Carbamazepine (CBZ), which has anti-cholinergic properties and some other AEDs (e.g. phenytoin) can cause fatal cardiac arrhythmias when the recommended dose is exceeded. Abrupt withdrawal of CBZ can increase sympathetic activity in sleep (12).

Autonomic function in peripheral or central nervous system diseases are evaluated using a number of clinical and neurophysiological tests which have been developed, validated and successfully applied in a clinical setting. Vasomotor response can be tested using transcranial Doppler sonography. It is assumed that flow changes during hyperventilation or breath-holding are due to altered resistance caused by changes in the diameter of vessels distal to the M1 segment of the middle cerebral artery (13). One study have investigated the effects of repetitive transcranial magnetic stimulation delivered as theta burst stimulation on cerebrovascular hemodynamics during simultaneous transcranial Doppler monitoring (14).

Most previous studies have evaluated patients with neurophysiological tests, but autonomic cardiovascular regulatory (vasomotor system) center as a part of autonomic system has been studied in less detail $(15,16)$.

In this case-control prospective study, we aimed to evaluate the vasomotor system control by applying simple, easily performed clinical function tests to a group of randomly selected, generalized idiopathic epileptic patients. In addition, the study attempted to investigate whether certain clinical or therapeutic characteristics are related to an increase risk for vasomotor system abnormalities.

\section{Materials and Methods}

\section{Subjects}

The study was approved by the Ethical Committee of Zanjan University of Medical Sciences.

Sixty-two consecutive patients who visited the outpatient epilepsy clinic of Vali-e-Asr Hospital participated in the study between May 20 and September 20, 2011. Subjects enrolled in this study were of ages between $15-45$ years, cognitively functional and were diagnosed with idiopathic generalized epilepsy according to ILAE criteria. Epilepsy was determined using the inpatientoutpatients medical records including EEG and neuroimaging studies (1). Being diagnosed for at least 3 months prior to the study and receiving unchanged mono-therapeutic regime for the past 3 months were the other inclusion criteria. Sixty-two sex and age matched healthy individuals, who were family members of the patients or their friends or hospital and university staff were enrolled as controls. None of the participants had any cardiovascular or centrally acting medication with a known effect on autonomic nervous system with the exception of the antiepileptic agents prescribed by the responsible neurologist. Those with cardiovascular disease (including arrhythmias), respiratory, hepatic, renal or autoimmune disorders, diabetes mellitus, viral or bacterial infection, hereditary or other type of neuropathy, physical trauma, and pregnancy were excluded from this study. Any other type of epilepsy including partial, absence, or any psychological problem such as anxiety or depression disorder or unwillingness to participate or poor compliance excluded subjects from our study.

Information of demographic and medical data of the subjects form including age, sex, family history of epilepsy or other neurological disease, duration of disease, duration of treatment, type of antiepileptic agents, the last attack and subjective symptoms of autonomic dysfunction was completed for all of the participants. Written informed consent was obtained from all the subjects before the study.

For evaluation of vasomotor system function 4 clinical tests were chosen and performed.

\section{Experiment Protocol}

This study was performed in Vali-e-Asr Hospital, Department of Neurology. Subjects were asked to refrain from consuming caffeine and alcohol and were told not to exercise prior to each test. They were seated comfortably in a quiet, dimly lit room (mean temperature 21.4 , range $18-28{ }^{\circ} \mathrm{C}$ ). Before each test, the subjects wore short pants and T-shirts and rested $20 \mathrm{~min}$ to ensure hemodynamic stabilization. Continuous non-invasive recording of beat was done using beat finger blood pressure and heart rate by the Sazegan Gostar device and intermittent brachial blood pressure was measured with an automated sphygmomanometer. Sphygmomanometer cuff was tied to the non-dominant arm and at the end of the last test was opened. All processes were explained to the participants before testes were started. Ample time was given between two consecutive tests for blood pressure and heart rate normalization before the next test was started.

Cold Pressor Test (Cutaneous Cold)

This cardiovascular test is performed by immersing the hand into an ice water container (temperature about $4^{\circ} \mathrm{C}$ ) for 2 minutes. Blood pressure and heart rate were measured before and after the test. Sensory afferent nerves trigger a systemic sympathetic activation leading to marked vasoconstriction. The result is a $15-20 \mathrm{mmHg}$ rise in blood pressure due to catecholamine release and border line response is defined as an increase of $10-15 \mathrm{mmHg}$ (17-19).

\section{Hand Grip Test}

The subjects were tested while sitting in comfortable position. Each individual was asked to squeeze a handgrip dynamometer (Tadbir-Kalay Company, made in USA: www.tadbirkala.ir) with their dominant hand, exerting the maximum possible force they could apply. This measurement was termed the maximum voluntary 
contraction (MVC). After a 10 min rest period, each subject was asked to maintain 30\% MVC for 3-5 min while breathing normally. No other body movement is allowed. Blood pressure and heart rate were registered before and after test. Increase in diastolic pressure over $15 \mathrm{mmHg}$ is considered as a normal and between 11$15 \mathrm{mmHg}$ is considered as borderline response (17-19).

\section{Valsalva Maneuver}

Valsalva maneuver is performed by blowing into a closed airway with moderate force (a force enough to hold the mercury column at $40 \mathrm{mmHg}$ for 15 seconds). Variations of the maneuver can be used in medical examination either as a test for cardiac function or autonomic nervous control of the heart. Changes in blood pressure and heart rate were recorded for this maneuver (17-19).

\section{Mental Arithmetic Test}

The subjects were given the number 1000, and told to count towards zero by subtracting 7 each time within 4 minutes in a noisy environment, and to answer as quickly as possible. Again, blood pressure and heart rate were measured before and after the test (17-19).

\section{Statistical Analyses}

Standard statistical methods were used for the calculation of mean \pm standard deviation (SD). An independent sample test, paired sample test, chi-square test, and one-way analysis of variance (ANOVA) were employed for statistical analysis of data where appropriate, using SPSS 16. The $\mathrm{p}<0.05$ level was considered statistically significant.

\section{Results}

\section{Baseline}

Out of 124 subjects assessed in this study, 62 had idiopathic generalized epilepsy and 62 sex and age-matched individuals were healthy controls. Their baseline characteristics are shown in Table 1. Mean age of epileptic patients was 24 years (ranges of 15-43) and mean age of control group was 26.7 years (ranges of 17-42). Majority of subjects $(96.7 \%$ in control group and $95.2 \%$ in patient group) had no other neurologic problem. Positive family history of epilepsy was found in $21 \%$ of case and $9.7 \%$ of control group. There was no family history in $98.4 \%$ of epileptic subjects. But $6.5 \%$ of control group mentioned 3 strokes and 1 dementia in their first degree family members.

We found that, $80.6 \%$ of case group suffered generalized idiopathic seizure for 1 year or more and $12.9 \%$ of them suffered more than 10 years. At least one attack were reported by $72.6 \%$ patients during the year prior to the examination. The most frequent antiepileptic drugs were valproate sodium and carbamazepine. Anti-epileptic agents are illustrated in Figure 1.

Some of subjective common vasomotor dysfunction symptoms of participants were asked in the questionnaire and are shown in the Figure 2. More than $50 \%$ did not feel any vasomotor discomfort ( $50 \%$ in patient and $60 \%$ in control group).

\section{Vasomotor Dysfunction for the Groups}

As shown in Table 2, abnormal score in the cold pressor test was seen in $59.7 \%$, Valsalva maneuver in $64.5 \%$, and mental arithmetic test in $33.9 \%$ of patients. These results were significantly different from the control group $(\mathrm{p}<0.05)$. In $35.5 \%$ of the patient group after cold pressor test, $43.5 \%$ after Valsalva maneuver and $11.3 \%$ after mental arithmetic test, no changes in both blood pressure and heart rate were seen. No significant increase in heart rate compared with baseline was observed after cold pressor test in approximately $47 \%$ of epileptic patients. This abnormality was observed in only $9.7 \%$ of control group and the difference in heart rate response was statistically meaningful $(\mathrm{p}<0.05)$.

When normal hand grip test was defined as an increase more than $11 \mathrm{mmHg}$ in diastolic pressure, no significant difference between the two groups was seen. When abnormality was defined as an increase in only one or none of the parameters of systolic blood pressure, diastolic blood pressure or heart rate, $43.5 \%$ in the patient group versus $14.5 \%$ in controls had abnormal results with a significant difference $(\mathrm{p}<0.05)$.

Comparison of vasomotor system function tests according to age distribution including 15-24, 25-34, and over 35 years old revealed a significant difference of abnormal Valsalva maneuver in all age groups of patients and controls and cold pressor response under 35 years old $(\mathrm{p}<0.05)$. Abnormality of mental arithmetic test was only seen between $15-25$ year olds $(\mathrm{p}=0.004)$. In handgrip test, values in both groups were not comparable in any age categories.

Sex was not found to be a factor affecting cardiac function tests, except in mental arithmetic test. We did not find any significant difference in abnormal vasomotor response according to duration of epilepsy, duration of treatment, and time freedom from attack. Also, no significant difference was found when neurophysiological test results were compared according to antiepileptic agents' types.

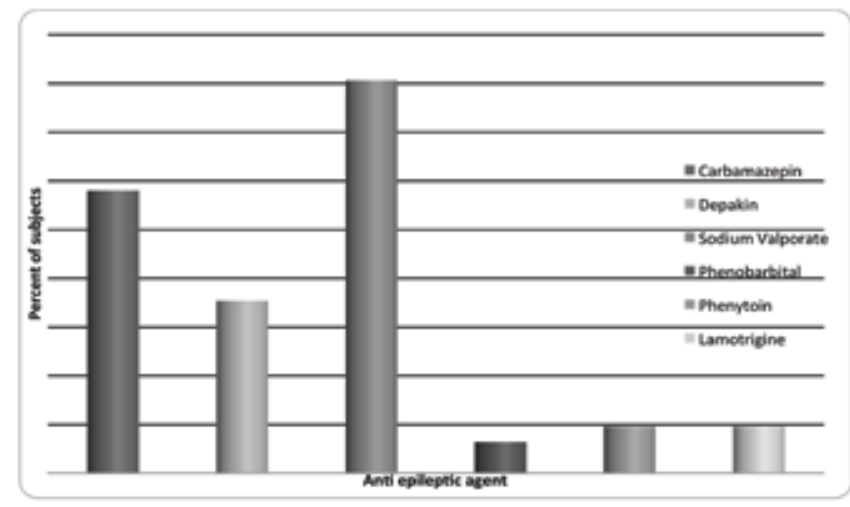

Figure 1. Distribution of antiepileptic agents in epileptic group

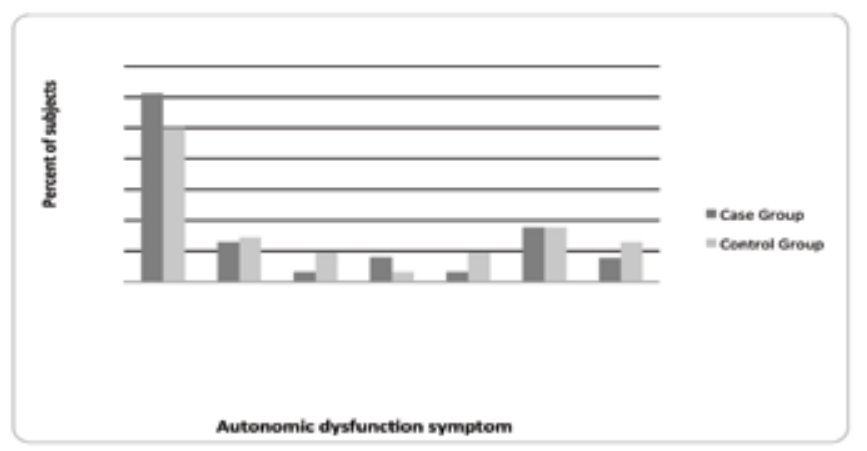

Figure 2. Distribution of subjective autonomic dysfunction symptoms in patient and control groups 
Table 1. Baseline characteristic of patient and control groups

\begin{tabular}{lclll}
\hline Characteristics & & $\begin{array}{l}\text { Patient } \\
\text { group } \\
(\%) \\
\mathbf{n}=62\end{array}$ & $\begin{array}{l}\text { Control } \\
\text { group (\%) } \\
\mathbf{n}=62\end{array}$ & $\begin{array}{l}\text { Total (\%) } \\
\mathbf{n}=124\end{array}$ \\
\hline & $15-24$ & $36(58.1)$ & $30(48.4)$ & $66(53.2)$ \\
Age categories & $25-34$ & $15(24.2)$ & $20(42.3)$ & $35(28.2)$ \\
(years) & Male & $32(51.4)$ & $27(43.5)$ & $59(47.4)$ \\
& Female & $30(48.4)$ & $35(56.5)$ & $65(52.4)$ \\
Sex & High & $34(54.8)$ & $9(14.5)$ & $43(34.7)$ \\
& school & & $12(19.4)$ & $23(18.5)$ \\
& Diploma & $9(14.5)$ & $7(11.3)$ & $16(12.9)$ \\
Education & University & $19(30.7)$ & $46(74.2)$ & $65(52.4)$ \\
\hline
\end{tabular}

\section{Discussion}

This study indicates that the cardiovascular responses to certain physiological stimuli were impaired in patients with generalized idiopathic epilepsy receiving monotherapy compared to the sex and age-matched healthy control group. Abnormal response which was defined as inadequate increase in blood pressure or heart rate due to sympathetic vasoconstriction failure was seen in all clinical tests including cold pressor, Valsalva maneuver, mental arithmetic and hand grip test.

Although near to $55 \%$ of patients did not mention any autonomic dysfunction symptoms such as orthostatic hypotension, palpitation and diaphoresis. Clinical autonomic tests revealed underlying autonomic disturbance and possible vulnerability of these patients to cerebral or cardiovascular symptoms or even sudden unexpected death.

Autonomic modulation is associated with suppressed or more variable parasympathetic and sympathetic cardiovascular responses. Variations in blood pressure and heart rate during orthostasis and cold pressor test are significantly higher in patients with partial epilepsy than in control subjects (20-22). In patients with temporal lobe epilepsy, measurement of heart-rate

Table 2. Vasomotor function tests comparison between case and control groups

\begin{tabular}{|c|c|c|c|c|}
\hline Test & Response & $\begin{array}{l}\text { Case group } \\
(\%) \mathrm{n}=62\end{array}$ & $\begin{array}{l}\text { Control group } \\
\text { (\%) } \mathrm{n}=62\end{array}$ & $\mathrm{p}$ value \\
\hline \multirow[t]{3}{*}{ Cold pressor } & Normal response 3 & $25(40.3)$ & (79) 49 & \\
\hline & Borderline $^{4}$ & $(24.2) 15$ & $(9.76)$ & $<0.001^{*}$ \\
\hline & Abnormal response ${ }^{5}$ & $(35.5) 22$ & $(11.3) 7$ & \\
\hline \multirow[t]{3}{*}{ Valsalva maneuver } & Normal response 3 & (35.5) 22 & $(88.7) 55$ & \\
\hline & Borderline ${ }^{4}$ & (21) 13 & (3.2) 2 & $<0.001^{*}$ \\
\hline & Abnormal response 5 & $(.543) 27$ & $(8.1) 5$ & \\
\hline \multirow[t]{3}{*}{ Mental arithmetic test } & Normal response 3 & $(66.1) 41$ & (88.7) 55 & \\
\hline & Borderline $^{4}$ & 22.6)) 14 & (4.8) 3 & $<0.021^{*}$ \\
\hline & Abnormal response 5 & $(11.3) 7$ & $(6.5) 4$ & \\
\hline \multirow[t]{3}{*}{ Hand grip1 } & Normal response & (145)0 & 15 & \\
\hline & Increase in DBP $>11 \mathrm{mmHg}$ & $(14.5) 9$ & (24.2) & $0173 \mathrm{y}$ \\
\hline & $\begin{array}{l}\text { Abnormal response } \\
\text { Increase in } \mathrm{DBP}<11 \mathrm{mmHg}\end{array}$ & $(85.5) 53$ & 75.8))47 & \\
\hline \multirow[t]{3}{*}{ Hand grip 2} & Normal response & & & \\
\hline & $\begin{array}{l}\text { Increase in two or more parameters of SBP. } \\
\text { DBP and HR }\end{array}$ & $(56.5) 35$ & $(85.5) 53$ & $<0.001^{*}$ \\
\hline & Abnormal response & (43.5) 27 & $(14.5) 9$ & \\
\hline $\begin{array}{l}\text { Hand grip was defined as an increase over } \\
\text { Hand grip was defined as an increase, at le } \\
\text { Increase in both SBP and DBP parameters } \\
\text { Increase in one parameter of SBP or DBP } \\
\text { No obvious change in parameters } \\
{ }^{*} \text {-p value }<0.05 \text { is considered significant }\end{array}$ & $\begin{array}{l}\text { tiastolic } 11 \mathrm{mmHg} \\
\mathrm{t} \text { in two of systolic, diastolic blood pressure or hear } \\
\text { ore than } 20 \mathrm{mmHg}\end{array}$ & & & \\
\hline
\end{tabular}


variability from short-term ECG recordings showed cardiovascular dysregulation (20-22). In these patients, not only heart rate is variability reduced, but also is long-term fractal organization, and complexity of heart rate dynamics is apparently altered $(22,23)$.

Interictal cardiovascular regulatory system function in 84 patients with epilepsy was assessed using standardized cardiovascular reflex tests and indicated changes in heart rate and blood pressure at rest and after Valsalva maneuver. Reduced heart rate responses to Valsalva maneuver were noted in patients receiving benzodiazepine agents as monotherapy and in patients receiving benzodiazepine agents during deep breathing $(24,25)$.

Seventy-one consecutive epileptic patients with partial or generalized seizures and 71 sex and age-matched controls took a battery of neurophysiological tests which consisted of sensory conduction of sural nerve; $\mathrm{R}-\mathrm{R}$ interval variation during normal and deep breathing; Valsalva maneuver and tilt test. We found that, $42.2 \%$ of patients had abnormal measurement in at least one of the parameters and Valsalva was the most frequently abnormal one (31\% of patients) $(26,27)$.

Our results consistent with previous studies suggested that simple neurophysiological tests were suitable for screening purposes and were able to show suppressed cardiac autonomic control in epileptic patients. A suppressed sympathetic or raised parasympathetic tone was reported in a group of 21 patients with temporal lobe epilepsy (2). An imbalance towards increased parasympathetic activity was also demonstrated by 123 I metaiodobenzylguanidine-SPECT analysis (28). However the autonomic imbalance in the opposite direction, such as increased sympathetic and decreased parasympathetic activity, was demonstrated in a study of 49 patients with generalized tonicclonic seizures (29).

In our study, antiepileptic agent type did not influence the response of patients to vasomotor function tests. In contrast with our study, some results demonstrated that benzodiazepine agents may suppress both parasympathetic and sympathetic functions in newly diagnosed epileptic patients (30).

In Bek study cerebrovascular reserve evaluated in idiopathic generalized epilepsy patients comparing healthy volunteers using transcranial Doppler ultrasonography (TCD). Cerebrovascular reactivity was evaluated by means of the breath-holding index. Insonation depth and basal velocity were symmetrical and not significantly different between the two groups. Cerebrovascular reserve was increased in epilepsy patients. This should not be accepted as an abnormality, but might have been the result of an adaptive mechanism that protects the brain from hypoxic challenges due to seizure apnea (31).

Mullers study shows that vasomotor reactivity shown by transcranial Doppler ultrasound correlates with cerebral blood flow changes even when different vasodilatory stimuli were used. In cooperative patients, the breath-holding maneuver as vasodilatory stimulus seems clinically useful for a first estimation of cerebral vasomotor reactivity (32).

Some studies indicate that antiepileptic agents may help to improve the cardiac autonomic function impairment in epileptic patients. For example, interictal autonomic dysfunction (parasympathetic disturbance) could be improved after achieving clinical recovery $(21,33)$. Ansakorpi et al. showed that HRV parameters the patients with partial epilepsy came close to those in control group after beginning anticonvulsant drug therapy (20). Thus, we require designing a broader study concerning the effects of antiepileptic agents in patients with autonomic symptoms.

\section{Conclusion}

To our knowledge, our paper highlights a topic that has not been explored in literature before, except for a recent study which evaluated electrocardiographic changes in children with epilepsy in the interictal phase (34). In this case-control prospective study, we assessed the vasomotor system control by applying simple, easily performed clinical function tests in generalized idiopathic epileptic patients.

In addition, the study attempted to investigate whether certain clinical or therapeutic characteristics were related to an increased risk for vasomotor system.

\section{Acknowledgment}

This study has been funded by Zanjan University of Medical Sciences. We would like to thank the staff of the Department of Neurology of Vali-e-Asr Hospital for their help. Finally, we wish to thank all the patients for participating in this study.

\section{References}

1. Devinsky O. Effects of Seizures on Autonomicand Cardiovascular Function Epilepsy Currents 2004;4:43-46.

2. Tomson T, Ericson M, Ihrman C, Lindblad LE. Heart rate variability in patients with epilepsy. Epilepsy Res 1998;30:77-83.

3. Mameli O, Caria MA, Melis F, Severino C, Tavera C, Mameli P, Mameli $\mathrm{S}$. Autonomic nervous system activity and life threatening arrhythmias in experimental epilepsy. Seizure 2001;10:269-278.

4. Opherk C , Coromilas J, Hirsch LJ. Related heart rate and EKG changes in 102 seizures: analysis of influencing factors. Epilepsy Res 2002;52:117-127.

5. Leutmezer F, Schernthaner C, Lurger S, Potzelberger K, Baumgartner C. Electrocardiographic changes at the onset of epileptic seizures. Epilepsia 2003;44:348-354.

6. Freeman R, Schachter SC. Autonomic epilepsy. Sem Neurol 1995;15:158-66.

7. Yu H, Yen D, Yiu C, Chung W, Lirng J, Su M. Pilomotor seizures. Eur Neurol 1998;40:19-21.

8. Scoppetta C, Casali C, D_Agostini S, Amabile G, Morocutti C. Pilomotor epilepsy. Funct Neurol 1989;4:283-6.

9. Hori T, Kiyohara T, Shibata M, Oomura Y, Nishino H, Aou S, Fujita I. Responsiveness of monkey preoptic thermosensitive neurons to non-thermal emotional stimuli. Brain Res Bull 1986;17:75-82.

10. Asami T, Hori T, Kiyohara T, Nakashima T. Convergence of thermal signals on the reticulospinal neurons in the midbrain, pons and medulla oblongata. Brain Res Bull. 1988;20:581-96.

11. Hennessy MJ, Tighe MG, Binnie CD, Nashef L. Sudden withdrawal of carbamazepine increases cardiac sympathetic activity in sleep. Neurology 2001;57:1650-1654.

12. Skydell JL, Machleder HI, Baker JD, Busuttil RW, Moore WS. Incidence and mechanisms of post-carotid endarterectomy hypertension. Arch Surg 1987;122:1153-1155.

13. Bek S, Kaşikçi T, Genç G, Demirkaya S, Odabaşi Z. Samenvatting Vasomotor properties of the M2 segment of the middle cerebral artery. J Neurol 2010;257;556-562.

14. Pichiorri F, Vicenzini E, Gilio F, Giacomelli E, Frasca V, Cambieri C, Ceccanti M, Di Piero V, Inghilleri M. Effects of intermittent theta burst stimulation on cerebral blood flow and cerebral vasomotor reactivity. J Ultrasound Med 2012;31:1159-1167.

15. Hirschl M, Kundi M, Hirsch MM, Liebisch B, Magometschnigg D. Blood pressure responses after carotid artery surgery: relationship to post operative baroreceptor sensitivity. Am J Med 1993;33:463-468. 
16. Hirschl M, Kundi M, Blazek G. Five year follow up of patients after thromboendarectomy of the internal carotid artery. Relevance of baroreceptor sensitivity. Stroke 1996;27:1167-1172.

17. Ropper AH, Samuel MA. Adams and Victor's Principles of Neurology. 9thed. New York: Mc Grow-Hill. 2004

18. Akinola A, Mathias CJ, Mansfield A, Thomas D, Wolfe J, Nicolaides AN, Tegos T. Cardiovascular, autonomic, and plasma catecholamine responses in unilateral and bilateral carotid artery stenosis. J Neurol Neurosurg Psychiatry 1999;67:428-432.

19. Labuz-Roszak B, Pierzchaca K. Assessment of autonomic nervous system in patients with epilepsy in the interictal state. A pilot study. Neurol Neurochir Pol 2009; 43:330-336.

20. Isojarvi JI, Ansakorpi H, Suominen K, Tolonen U, Repo M, Myllyla VV. Interictal cardiovascular autonomic responses in patients with epilepsy. Epilepsia 1998;39:420-426.

21. Ansakorpi H, Korpelainen JT, Suominen K, Tolonen U, Myllyla VV, Isojarv JI. Interictal cardiovascular autonomic responses in patients with temporal lobe epilepsy. Epilepsia 2000;41:42-47.

22. Devinsky O, Perrine K, Theodore WH. Interictal autonomic nervous system function in patients with epilepsy. Epilepsia 1994;35:199-204.

23. Ansakorpi H, Korpelainen JT, Huikuri HV, Tolonen U, Myllyla VV, Isojarvi JI. Heart rate dynamics in refractory and well controlled temporal lobe epilepsy. J Neurol Neurosurg Psychiatry 2002;72:26-30.

24. Hilz MJ, Devinsky O, Doyle W, Mauerer A, Dütsch M. Decrease of sympathetic cardiovascular modulation after temporal lobe epilepsy surgery. Brain 2002;125:985-995.

25. Isojiirvi J, Ansakorpi H, Suominen K, Tolonen U, Repo M, Myllyla V. Interictal Cardiovascular Autonomic Responses in Patientswith Epilepsy. Epilepsia 1998;39:420-426.
26. Freeman R. Assessment of cardiovascular autonomic function. Clin Neurophysiol 2006;117:716-730.

27. Chroni E, Sirroua V, Trachani E, Sakellaropoulos G, Polychronopoulos P Interictal alterations of cardiovagal function in chronic epilepsy. Epilepsy Research 2009;83:117-123.

28. Druschky A, Hilz MJ, Hopp P, Platsch G, Radespiel-Tröger M, Druschky K, Kuwert T, Stefan H, Neundörfer B. Interictal cardiac autonomic dysfunction in temporal lobe epilepsy demonstrated by [123I]metaiodobenzylguanidineSPECT. Brain 2001;124:2372-2382.

29. Evrengül H, Tanriverdi H, Dursunoglu D, Kaftan A, Kuru O, Unlu U, Kilic M. Time and frequency domain analyses of heart rate variability in patients with epilepsy. Epilepsy Res 2005;63:131-139.

30. Persson H, Ericson M, Tomson T. Carbamazepine affects autonomic cardiac control in patients with newly diagnosed epilepsy. Epilepsy Research 2003;57:69-75.

31. Bek S, Kaşikçi T, Koç G, Genç G, Demirkaya S, Gökçil Z, Odabaşi Z. Cerebral vasomotor reactivity in epilepsy patients.Journal of Neurology 2010;257:833838.

32. Müller M, Voges M,Piepgras U, Schimrigk K. Assessment of Cerebral Vasomotor Reactivity by Transcranial Doppler Ultrasound and Breath-Holding. Stroke 1995;26:96-100.

33. Hallioglu O, Okuyaz C, Ertan Mert E, Makharoblidze K. Effects of antiepileptic drug therapy on heart rate variability in children with epilepsy. Epilepsy Research 2008;79:49-54

34. Borzoee M, Rafiei SM. Electrocardiografic changes in seizure disorder. Iran j med scei 2003;28:116-118. 